\title{
Further Evidence for Pre-metamorphosis Larval Eye Reduction in the Holometabola (Insecta: Mecoptera: Panorpa vulgaris IMHOFF \& LABRAM, 1836)
}

With 3 figures and 2 tables

BRIAN D. SALTIN ${ }^{1}$

${ }^{1}$ Inneringer Straße 10, 72513 Hettingen, Germany. - brian.saltin@gmx.de

Published on 2015-06-30

\section{Summary}

Larvae of Panorpa are eye developmentally unusual. They possess a multi-lense complex-eye-like visual organ, which was found not to be part of the later adult eye. A highly significant deviation in the ommatidia number during the larval stages was found, with instar 3 (of 4 ) having most ommatidia.

\section{Key words}

Eye, Mecoptera, Panorpa, Metamorphosis, Development

\section{Zusammenfassung}

Die Larven der Gattung Panorpa weisen eine ungewöhnliche Augenentwicklung auf. Sie besitzen ein aus vielen Linsen bestehendes, komplexaugenähnliches Organ, welches nicht zu einem Teil des späteren Adultauges wird. Die einzelnen Larvenstadien unterscheiden sich hochsignifikant in der Anzahl der Ommatidien: das dritte von vier Larvenstadien besitzt die meisten Ommatidien.

\section{Introduction}

No matter what the actual phylogenetic grouping amongst the Mecoptera is, they are considered to be less derived in respect to eye development than other insects (FrIEDRICH et al. 2006). Beside the remarkably facet-eye-like organisation of the larval eyes (see Fig. 1), which sets them clearly apart from simple stemmata-possessing groups, their less derived state of eye development marks them as an excellent object for the study of eye development in general. The first aim was to show by histology and TEM, which both can only provide isolated information about one moment during development, what happens to the components, i. e., the cells and the organelles of the larval eye, once the metamorphosis sets in. The second was to re-check previous reports of a constant number of omma- tidia during post-embryonal development (BusCHBECK et al. 2008; Friedrich 2006; FrIEdrich 2008; FrIEdrich et al. 2011; PAulus 1979; PAulus 1989) considering new data on developmental changes eg. in Thysanoptera (Kumm 1997) or Coleoptera (FrIEDrich et al. 2006; Friedrich et al. 2011; SCHUlz et al. 1984).

The blueprint of a typical insect ommatidium - be it holo- or hemimetabolous in origin

Typically an insect ommatidium consists of eight retinular cells, four sempercells and two main pigment cells (ANDERSON 1978; MELzer et al. 2000; Nowel 1981). In the case 


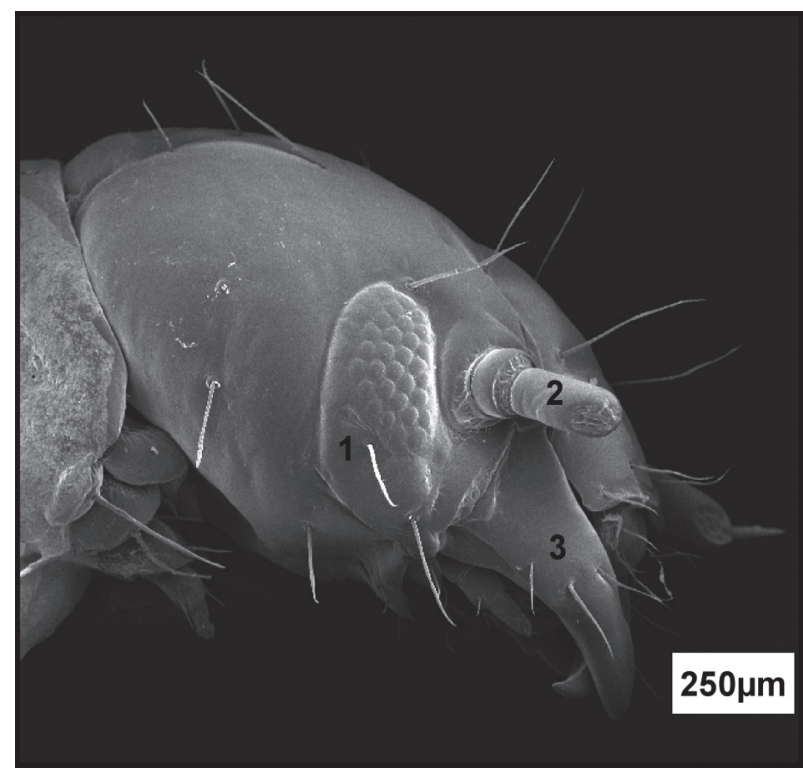

Fig. 1: SEM side view of a 3rd instar larvae head and eye, notice the well defined rows of ommatidia. Figure annotations: 1: eye; 2: antenna; 3: mandible.

of a hemimetabolous development a sequential adding of new ommatidia adjacent to older ones takes place leading to adults with higher ommatidia number than the larva (ANderson 1978; Friedrich 2006; Meinertzhagen 1973; Nowel 1981; Paulus 1979; Paulus 1989).

In the holometabolous development, the embryonal eye development is partly suppressed until metamorphosis and conducted in cell invaginations, which are developmentally independent from JH (juvenile hormone) (Meinertzhagen 1973; Meinertzhagen 1975; Truman et al. 1999; Truman et al. 2002). The development starts with the $\mathrm{R} 8$ ( $\mathrm{R}=$ Retinularcell), followed by the so called five-cell-cluster (R58+R2/5+R3/4) and is completed to the usual eight-cell-cluster by adding the R1/6 and R7 cells (Friedich et al. 2011; SAlzer et al. 2009; Tomlinson 1988; WolfF et al. 1993).

The development follows a morphogentic furrow, which sweeps from posterior to anterior, initiation cell proliferation and differentiation (CHAMPLINE et al. 1998; EgelhaAf et al. 1988; Friedrich et al. 2011; Meinertzhagen 1975; Ready 1989; WolfF et al. 1993; WOLPERT 1969). Thus the basic difference between holometabola and hemimetabola regarding eye development is continuous growth with addition of ommatidia in hemimetabola and de novo development in the metamorphic pupal stage following a developmental grading in holometabola.

\section{State-of-the-art knowledge regarding eye development in Panorpa}

Although some species have recently been investigated with TE-Microscopy eg. Panorpa dubia CHOU \& WANG,
1981 and Panorpodes kuandianensis ZHONG, ZHANG \& Hua, 2011 by Chen and colleagues (Chen et al. 2012; Chen et al. 2013) or even Panorpa vulgaris by MeLzer (1994) no coherent developmental model has surfaced yet. The problematics have already been keenly identified by Bierbrod t back in the 1940s. She stated that the actual developmental step takes place in the early pre-puppa, which weren't at her disposal (BIERBRODT 1942). The larval ommatidium consists of one biconvex lense, two primary pigment cells, four sempercells and eight retinular cells in two layers, this overall structure has been deemed highly conserved by Friedrich und Jackowska (Friedrich et al. 2006; PAUlus 1979). According to LAND there are only two ways to optimize optical resolution in an eye: $1^{\text {st }}$ enlarging the eye while keeping the same receptor density - the solution in vertebrates -, or $2^{\text {nd }}$ multiplication of small eye units - the solution realized in arthropod eyes (LAND et al. 2002).

All comes down to the question wether or not the stemmata of the holometabola are an autapomorphic feature. In this context it would be interesting to know wether stemmata are secondarily simplified adult eyes leading to the complex eyes of larva being a tertiary variation on stemma, this is the thesis favoured in literature (BEUTEL et al. 2010; Friedrich et al. 2006; PAUlus 1979; PAUlus 1986a, 1989b; Kristensen 1995; Melzer et al. 1989) but it is also occasionally contradicted, eg. BEUTEL, who questions the polarity of the compound eye character state (Beutel et al. 2006). Alternatively they could be a completely new development or the stemma might be a secondary reduction which happened after the emergence of holometabola, not necessarily individually but in different groups, this is clearly less likely. Which alternative best explains the stemmata could be tested by verifying the situation in the eye development of less derived groups which lead FrIEDRICH et al. to the statement „To confirm this idea, it will be necessary... to study the cellular dynamics of larval and adult eye development in the less derived visual systems of holometabola species such as scorpion flies (Mecoptera)“ (FrIEDRICH et al. 2006).

\section{Materials \& Techniques}

\section{Animal obtention}

All animals were taken of my own breeding stock. Panorpa vulgaris was kept and reared according to the guidelines provided by RotTMAR (1966) with the exception that fish food (white bloodworms) was substituted for the advised feeding.

\section{Counting method}

20 head capsula of previously sedated, decapitated and fixed animals per instar have been counted using a Zeiss AxioCam MRc5 mounted on a Leica MZ125 binocular for documentation. Each individual was counted three times and averaged. 


\section{Statistics}

Using SPSS 21, the acquired data of ommatidia number of twenty individuals per instar have been analysed regarding equal distribution with Shapiro-Wilk-Test and regarding equal variance with Levene Statistic. According to the unequal distribution of one group (instar 4) further analysis was conducted non-parametrically with Kruskal-Wallis-Test followed up by a pairwise comparison with Mann-Whitney-U-Tests. Significance values have been conservatively Bonferroni corrected.

\section{Histology}

$5 \mu \mathrm{m}$ thick paraffin sections and $1,5 \mu \mathrm{m}$ semi-thin sections (embedded in hard aradlid colored with Stevenes Blue) were produced to complement the TEM studies.

\section{Fixation}

Animals for semi-and ultrathin sections were glutaraldehyde and osmiumtetroxide fixated. For the histological paraffin sections the specimens were fixed with FormolAcetic Acid-Ethanol.

\section{Results}

\section{Histology \& TEM}

In both histology and the TEM analyses it was possible to identify new as well as degrading larval ommatidia (see Fig. 2).

\section{Statistics}

The results of the statistic analyze of ommatidia number differences are summarized in Fig. 3, Tab. 1 and Tab. 2.

Tab. 1: Shapiro-Wilk and Levene Statistic and confidence intervals for instar $1-4$. Singling the $4^{\text {th }}$ larval stage out for not being evenly distributed.

\begin{tabular}{|l|l|l|}
\hline $\begin{array}{l}\text { Tests and test groups if } \\
\text { applicable }\end{array}$ & Test statistic & $\begin{array}{l}\text { Significance } \\
\text { values }\end{array}$ \\
\hline $\begin{array}{l}\text { Levene Statistic based on } \\
\text { mean (Median) }\end{array}$ & $\begin{array}{l}1,530(1,489) \\
\text { df1:3; df2:76 }\end{array}$ & $0,214(0,224)$ \\
\hline $\begin{array}{l}\text { Shapiro-Wilk Statistic 1 } \\
\text { Shapiro-Wilk Statistic 2 } \\
\text { Shapiro-Wilk Statistic 3 } \\
\text { Shapiro-Wilk Statistic 4 }\end{array}$ & $\begin{array}{l}0,950 \text { df:20 } \\
0,969 \text { df:20 }\end{array}$ & $\begin{array}{l}0,367 \\
0,084 \\
0,766 \\
\text { df:20 }\end{array}$ \\
\hline confidence intervals & lower border & upper border \\
\hline L1 & 28,83 & 31,50 \\
\hline L2 & 29,32 & 33,25 \\
\hline L3 & 34,15 & 37,05 \\
\hline L4 & 31,24 & 33,63 \\
\hline
\end{tabular}

\section{Discussion}

\section{Histology \& TEM}

Whereas only one individual was investigated in TEM, a pigment spot could be found many times in the histological sections, and also is mentioned in literature (BIERBRodt 1942; RotTMAR 1966) (unpublished

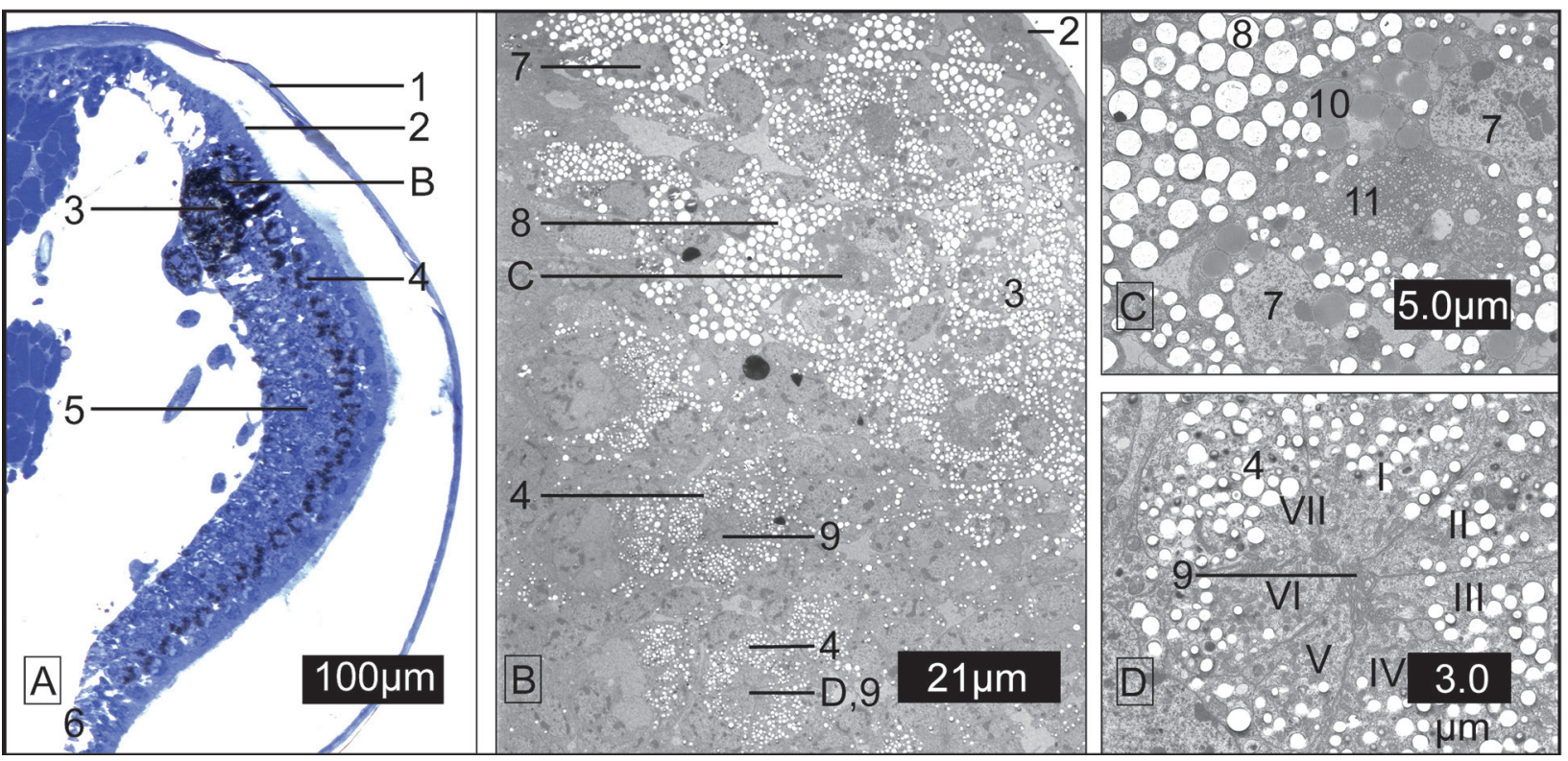

Fig. 2: A-D: A: eye segment of a transversal section through the first puppal stage head of Panorpa vulgaris, upper half of the picture dorsal, lower half ventral; B: TEM overview of the area of the pigment spot from the same specimen; C: detailed TEM picture of a degrading rhabdomer; D: detailed TEM picture of a developing rhabdomer.

Figure annotations: B: position of detail shown in part B; C: position of detail shown in part C; D: position of detail shown in part D; 1: puppal cuticula; 2: developing adult cuticula; 3: pigment spot; 4: area encirceld by pigment vesicles; 5: part of differentiation zone; 6: border of proliferation zone; 7: degrading nucleus; 8: large pigment vesicles; 9: group of rhabdom building retinular cells; 10: lipid vesicles aggregation sign of degradation; 11: degrading larval rhabdomer; I-VII: new developing retinular cells, numbered. 
Tab. 2: Kruskal-Wallis-Test and follow-up pairwise MannWhitney-U-Test in brackets the non-Bonferroni-corrected values are provided as well.

\begin{tabular}{|l|l|l|}
\hline Stage & Mean & $\begin{array}{l}\text { St Error } \\
(\text { for N=20) }\end{array}$ \\
\hline L1 & 31,17 & $\pm 0,64$ \\
\hline L2 & 31,28 & $\pm 0,94$ \\
\hline L3 & 35,6 & $\pm 0,69$ \\
\hline L4 & 31,62 & $\pm 0,96$ \\
\hline Sign. Comp. & K-W-Test & $\begin{array}{l}<0,001 \mathrm{df3} \\
\text { Chi^2: 22,29 }\end{array}$ \\
\cline { 2 - 3 } & M-W-U-Test & $\begin{array}{l}\text { M-W-U-Test } \\
\text { U Statistic }\end{array}$ \\
\hline L3:L1 & $\mathrm{a}<0,01$ & 38 \\
\hline L3:L2 & $\mathrm{a}<0,01$ & 82 \\
\hline L3:L4 & $\mathrm{a}<0,01$ & 64,5 \\
\hline
\end{tabular}

data). The histology data support the hypothesis on the degradation of the larval eye structures and the new development of adult eye ommatidia, as expected for a holometabolous insect. Since ommochromes cannot be metabolized (KAYSER 1979; LINZEN 1974) it remains unclear wether they are excreted or recycled, a precedent for the latter exists in Thysanoptera (KumM 1997). It seems neither to be a case like in the Chaoboridae where the adult eyes develop early (Brammer 1970; Melzer et al. 1991; Melzer et al. 1994a; Melzer 2009) nor like in the Nannochoristidae with more than one eye in the larval stage (Melzer et al. 1994b).

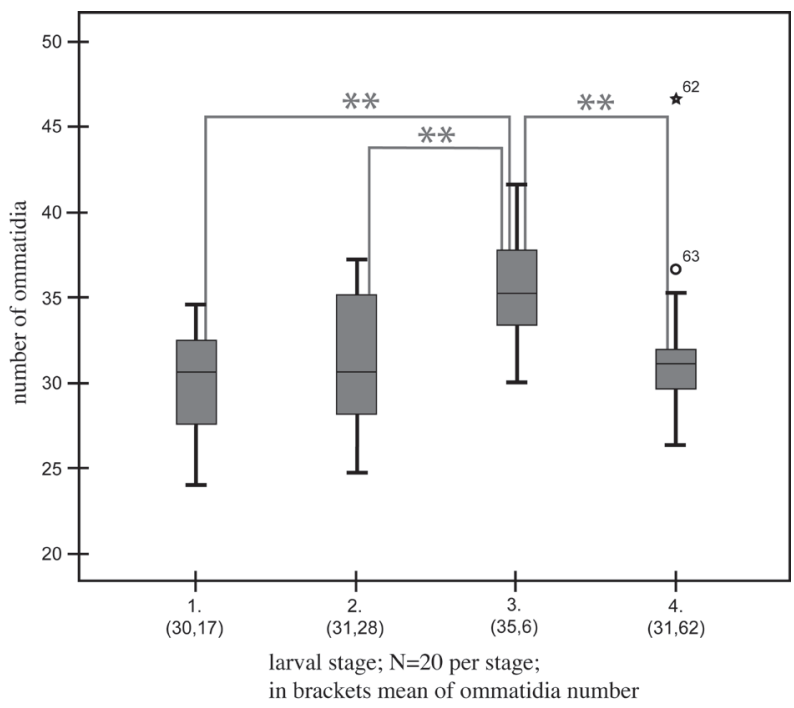

Fig. 3: Means of all four instars shown as Boxplots, significances are denoted as following * significant $(a<0,05)$, ** highly significant $(\mathrm{a}<0,01)$.

Histology could also show that one ommatidium is below one "Cornea lense", no fusion of ommatidia was found. Fusion of ommatidia is sometimes reported for larval eyes of other groups (BEUTEL et al. 2008; Liu et al. 2004; MANDAPAKA et al. 2006).
That Mecoptera possess true compound eyes if one follows a functional definition is in accordance with observations by GILBERT (1994).

\section{Placement of statistic results}

The $3^{\text {rd }}$ instar has significantly more ommatidia than the other three stages. Regarding the beginning of eye reduction there is a precedent in Coleoptera (FRIEDRICH et al. 2006; Friedrich et al. 2011) and Drosophila (Kenyon et al. 2003; Kumar 2001; Kumar et al. 2001b, 2001c). The fact that large instars have not only larger ommatidia but also more of them resembles a hemimetabolous development, but then Mecoptera are thought to be less derived in eye development than other holometabolous groups (FrIEdRICH 2006). An increasing number of larval ommatidia clearly contradicts earlier notions (BusCHBECK et al. 2008; PAulus 1989).

\section{Outlook}

Having shown this for Panorpa vulgaris with histology and statistics a broader, more general approach within the Panorpa relationship would be desirable. With the genomic tools available today referring to $1000 \mathrm{~K}$ project and the explicit knowledge of model organisms like Drosophila and red flour beetle genetics (DANIEL et al. 1999; ELLIS et al. 1993; FrIEDRICH 2003; FrIEDRICH et al. 1996; Friedrich et al. 2000; GEHRING 2002; HAYNIE et al. 1986; Helfrich-Förster et al. 2002; KLINGLer 2004; KoJIMA et al. 1991; Kumar 2001; Kumar et al. 2001a, 2001b, 2001c; Meinertzhagen 1973; Meinertzhagen 1989; Moses et al. 1991; Osorio 2007; Pappu et al. 2004; Plautz et al. 1996; QUIRING et al. 1994; SEN 2006; SERIKAKU et al. 1994; STEINBERG 1941; SuzuKi et al. 2000; WolfF et al. 1993; YASUYAMA et al. 1999) a molecular approach to in-vivo cell tracking might be feasible and probably rewarding. With this approach it would also be possible to track possible remains of the larval eye later on, which might be as small as 4 unpigmented cells if we consider the example of the Bolwig organ transformation into the Hofbauer-Buchner eyelet (Bolwig 1946; Friedrich 2008; Hofbauer et al. 1989; Helfrich-Foerster et al. 2002).

Beside either a ecological study of the larval behavior or an investigation of the cornea lenses' refraction properties as done for Scarab Beetles by McInTYRE (1985) could provide useful insight into the actual usage of the eyes by these burrowing animals.

\section{Acknowledgements}

I would like to thank Prof. Dr. O. Betz, Department of Evolutionary Biology of Invertebrates, Morphology and Ecology, University of Tuebingen and Dr. E. Weber of the Zoological Collections of Comparative Zoology, University of Tuebingen, for their counsel and material support, as well as Dr. G. Mickoleit for his advice and help getting started with rearing of Mecoptera. 
Final thanks go to the many people without whom this work would not have been possible: Paavo Bergmann, Monika Meinert, Christina Nitsche, Jürgen Rösinger, Prof. Dr. Ulrich Schraermeyer, University Eye Hospital Tuebingen, Julia Straube, Adrian Tröscher and Daniela Weide, mainly for technical support and proofreading.

\section{References}

Anderson, H. 1978: Postembryonic development of the visual system of the locust, Schistocerca gregaria. I. Patterns of growth and developmental interactions in the retina and optic lobe. - Journal of Embryology \& Experimental Morphology, Cambridge 45: 55-83.

Beutel, R. G.; Friedrich, F.; Hörnschemeyer, T.; Pohl, H.; Hünefeld, F.; Beckmann, F.; Meier, R.; Misof, B.; Whiting, M. F. \& Vilhelmsen, L. 2011: Morphological and molecular evidence converge upon a robust phylogeny of the megadiverse Holometabola. - Cladistics, Stockholm/New York 27 (4): 341-355.

Beutel, R. G.; Krogmann, L. \& Vilhelmsen, L. T. 2008: The larval head morphology of Xyela sp. (Xyelidae, Hymenoptera) and its phylogenetic implications. Journal of Zoological Systematics and Evolutionary Research, Oxford 46 (2): 118-132.

Beutel, R. G. \& Pohl, H. 2006: Endopterygote systematics - where do we stand and what is the goal (Hexapoda, Arthropoda)? - Systematic Entomology, London 31 (2): 202-219.

Bierbrodt, E. 1942: Der Larvenkopf von Panorpa communis L. und seine Verwandlung, mit besonderer Berücksichtigung des Gehirns und der Augen. Zoologische Jahrbücher. Abteilung für Anatomie und Ontogenie der Tiere, Münster 68 (1): 49-136.

BolwIG, N. 1946: Senses and sense organs of the anterior end of the house fly larvae. - CA Reitzel, Kobenhavn: pp. 82-217.

BRAMmer, J. D. 1970: The Ultrastructure of the Compound Eye of a Mosquito Aedes aegypti L. - Journal of Experimental Zoology, New Jersey 175 (2): 181-195.

BuschBECK, E. \& FrIEDRICH, M. 2008: Evolution of Insect Eyes: Tales of Ancient Heritage, Deconstruction, Reconstruction, Remodeling, and Recycling. - Evolution Education and Outreach, Heidelberg 1(4): 448-462.

Champlin, D. T. \& Truman, J. W. 1998: Ecdysteroids govern two phases of eye development during metamorphosis of the moth, Manduca sexta. Development, Cambridge 125 (11): 2009-2018.

Chen, Q.; LI, T. \& HuA, B. 2012: Ultrastructure of the Larval Eye of the Scorpionfly Panorpa dubia (Mecoptera: Panorpidae) with Implications for the Evolutionary Origin of Holometabolous Larvae. Journal of Morphology, Singapore 273 (6): 561-571.
Chen, Q.; Wel, Y. \& HuA, B. 2013: Fine Structure of the Ommatidia of the Short-Faced Scorpionfly Panorpodes kuandianensis (Mecoptera: Panorpodidae). - Microscopy Research and Technique, Hoboken 76 (8): 862-869.

Daniel, A.; Dumstrei, K.; Lengyel, J. A. \& HartenSTEIN, V. 1999: The control of cell fate in the embryonic visual system by atonal, tailless and EGFR signaling. Development, Cambridge 126 (13): 2945-2954.

EgelhaAf, A.; Altenfeld, H. \& Hoffmann, H.-U. 1988: Evidence for the priming role of the central retinula cell in ommatidium differentiation of Ephestia kuehniella. - Wilhelm Roux's archives of developmental biology, Wien 197 (3): 184-189.

Ellis, M. C.; O’Neill, E. M. \& Rubin, G. M. 1993: Expression of Drosophila glass protein and evidence for negative regulation of its activity in non-neuronal cells by another DNA-binding protein. - Development, Cambridge 119 (3): 855-865.

FrIEDRICH, M. 2003: Evolution of Insect Eye Development: First Insights from Fruit Fly, Grasshopper and Flour Beetle. - Integrative and Comparative Biology, Oxford 43 (4): 508-521.

Friedrich, M. 2006: Continuity versus split and reconstitution: Exploring the molecular developmental corollaries of insect eye primordium evolution. - Developmental Biology, San Diego 299 (2): 310-329.

FRIEDRICH, M. 2008: Opsins and cell fate in the Drosophila Bolwig organ: tricky lessons in homology inference. BioEssays, Hoboken, NJ 30 (10): 980-993.

Friedrich, M. \& Benzer, S. 2000: Divergent decapentaplegic Expression Patterns in Compound Eye Development and the Evolution of Insect Metamorphosis - Journal of Experimental Zoology Part B, New Jersey 288 (1): 39-55.

Friedrich, M.; Dong, Y. \& Jackowska, M. 2006: Insect Interordinal Relationships: Evidence from the Visual System. - Arthropod Systematics \& Phylogeny, Frankfurt/Main 64 (2): 133-148.

Friedrich, M.; Rambold, I. \& Melzer, R. R. 1996: The early stages of ommatidial development in the flour beetle Tribolium castaneum (Coleoptera, Tenebrionidae). - Development Genes and Evolution, Wien 206 (2): 136-146.

Friedrich, M.; Wood, E. J. \& Wu, M. 2011: Developmental Evolution of the Insect Retina: Insights From Standardized Numbering of Homologous Photoreceptors. - Journal of Experimental Zoology Part B, New Jersey 316B (7): 484-499.

Gehring, W. J. 2002: The genetic control of eye development and its implications for the evolution of the various eye-types. - The International Journal of Developmental Biology, Bilbao 46 (1): 65-73.

Gilbert, C. 1994: Form and Function of Stemmata in Larvae of Holometabolous Insects. - Annual Review of Entomology, Palo Alto 39: 323-349. 
Haynie, J. L. \& Bryant, P. J. 1986: Development of the Eye-Antenna Imaginal Disc and Morphogenesis of the Adult Head in Drosophila melanogaster. - Journal of Experimental Zoology, New Jersey 237 (3): 293-308.

Helfrich-Förster, C.; Edwards, T.; Yasuyama, K.; Wisotzki, B.; SChNeUwly, S.; STANeWSKy, R.; Meinertzhagen, I. A. \& Hofbauer, A. 2002: The Extraretinal Eyelet of Drosophila: Development, Ultrastructure, and Putative Circadian Function. - The Journal of Neuroscience, Washington, DC 22 (21): 9255-9266.

Hofbauer, A. \& Buchner, E. 1989: Does Drosophila Have Seven Eyes? - Naturwissenschaften, Heidelberg 76 (7): 335-336.

Kayser, H. 1979: Ommochrome formation and kynurenine excretion in Pieris brassicae: Relation to tryptophan supply on an artifical diet. - Journal of Insect Physiology, Philadelphia 25 (8): 641-646.

Kenyon, K. L.; Ranade, S. S.; Curtiss, J.; Mlodzik, M. \& Pignoni, F. 2003: Coordinating Proliferation and Tissue Specification to Promote Regional Identity in the Drosophila Head. - Developmental Cell, Cambridge, MA 5 (3): 403-414.

Kojima, T.; Ishimaru, S.; Higashuima, S.-I.; Takayama, E.; Akimaru, H.; Sone, M.; Emori, Y. \& SAIGO, K. 1991: Identification of a different-type homebox gene, BarH1, possibly causing $\operatorname{Bar}(B)$ and Om(1D) mutations in Drosophila. - Proceedings of the National Academy of Sciences, Washington, DC 88 (10): 4343-4347.

KRIstensen, N. P. 1995: Forty years insect phylogenetics. - Zoologische Beiträge N.F., New York 36: 83-124.

KumaR, J. P. 2001: Signalling pathways in Drosophila and vertebrate retinal development. - Nature Reviews Genetics, London 2 (11): 846-857.

Kumar, J. P. \& Moses, K. 2001a: EGF receptor and notch signaling act upstream of eyeless/Pax6 to control eye specification. - Cell, Cambridge, MA 104 (5): 687-697.

Kumar, J. P. \& Moses, K. 2001b: Expression of evolutionarily conserved eye specification genes during Drosophila embryogenesis. - Development Genes and Evolution, Wien 211 (8-9): 406-414.

Kumar, J. P. \& Moses, K. 2001c: The EGF receptor and notch signaling pathways control the initiation of the morphogenetic furrow during Drosophila eye development. - Developmental Biology, San Diego 128 (14): 2689-2697.

Kumm, S. 1997: Ontogenese des visuellen Systems von Franklinella occidentalis (PERgRANDE, 1895). - Halle: Universität Halle Inst. Zool. Fb. Biologie, Diplomarbeit: pp. 38.

Land, M. F. \& NiLsson, D.-E. 2002: Animal Eyes - 1st ed. Oxford University Press: pp. 221.

Linzen, B. 1974: The Tryptophan - Ommochrome Pathway in Insects. - Advances in Insect Physiology, London 10: 117-246.
LiU, Z. \& Friedrich, M. 2004: The Tribolium homologue of glass and the evolution of insect larval eyes. Developmental Biology, San Diego 269 (1): 36-54.

Mandapaka, K.; Morgan, R. C. \& Buschbeck, E. K. 2006: Twenty-Eight Retinas But Only Twelve Eyes: An Anatomical Analysis of the Larval Visual System of the Diving Beetle Thermonectus marmoratus (Coleoptera: Dytiscidae). - Journal of Comparative Neurology, Hoboken, NJ 497 (2): 166-181.

McIntyre, P. \& Caveney, S. 1985: Graded-Index Optics are Matched to Optical Geometry in the Superposition Eyes of Scarab Beetles. - Philosophical Transactions of the Royal Society Londen B, London 311 (1149): 237-269.

Meinertzhagen, I. A. 1973: Development of the compound eye ans optic lobe of insects. - In: Young, D. 1973: Developmental Neurobiology of Arthropods. Cambridge University Press, Cambridge: pp. 51-104.

Meinertzhagen, I. A. 1973: Fly Photoreceptor Synapses: Their Development, Evolution, and Plasticity - Journal of Neurobiology, Hoboken, NJ 20 (5): 276-294.

Meinertzhagen, I. A. 1975: The development of neuronal connection patterns in the visual systems of insects. - In: Porter, R.; Rivers, J. \& Ciba Foundation 1975: Cell Patterning - Ciba Foundation Symposium, Elsevier-Excerpta Medica-North Holland, Amsterdam 29: 265-289.

Melzer, R. R. 1994: Optic lobes of the larval and imaginal scorpionfly Panorpa vulgaris (Mecoptera, Panorpidae): A neuroanatomical study of neuropil organization, retinula axons, and lamina monopolar cells. - Cell and Tissue Research, Heidelberg 275 (2): 283-290.

Melzer, R. R. 2009: Persisting Stemma Neuropils in Chaoborus crystallinus (Diptera: Chaoboridae): Development and Evolution of a Bipartite Visual System. - Journal of Morphology, The Atrium Southern Gate Chichester West Sussex 270 (12): 1524-1530.

Melzer, R. R.; Michalke, C. \& Smola, U. 2000: Walking on insect paths? Early ommatidial development in the compound eye of the ancestral crustacean, Triops cancriformis. - Naturwissenschaften, Heidelberg 87 (7): 308-311.

Melzer, R. R. \& Paulus, H. F. 1989: Evolutionswege zum Larvalauge der Insekten - Die Stemmata der höheren Dipteren und ihre Abwandlung zum Bolwig-Organ. - Journal of Zoological Systematics and Evolutionary Research, Hoboken, NJ 27 (3): 200-245.

Melzer, R. R. \& Paulus, H. F. 1991: Morphology of the visual system of Chaoborus crystallinus (Diptera, Chaoboridae). I. Larval compound eyes and stemmata. - Zoomorphology, Heidelberg 110 (4): 227-238. 
Melzer, R. R. \& Paulus, H. F. 1994a: Post-larval development of compound eyes and stemmata of Chaoborus crystallinus (DE GeER, 1776) (Diptera: Chaoboridae): Stage-specific reconstructions within individual organs of vision. - International Journal of Insect Morphology and Embryology, Amsterdam 23 (3): 261-274.

Melzer, R. R.; Paulus, H. F. \& Kristensen, N. P. 1994b: The Larval eye of nannochoristid Scorpionflies (Insecta, Mecoptera). - Acta Zoologica, Hoboken, NJ 75 (3): 201-208.

Moses, K. \& Rubin, G. M. 1991: Glass encodes a sitespecific DNA-binding protein that is regulated in response to positional signals in the developing Drosophila eye. - Genes \& Development, Woodbury, NY 5 (4): 583-593.

Nowel, M. S. 1981: Postembryonic growth of the compound eye of the cockroach. - Journal of Embryology \& Experimental Morphology, Cambridge 62 (1): 259-275.

Osorio, D. 2007: Spam and the evolution of the fly's eye. - BioEssays, Hoboken, NJ 29 (2): 111-115.

PAppu, K. S. \& MARdon, G. 2004: Genetic control of retinal specification and determination in Drosophila. - The International Journal of Developmental Biology, Bilbao 48 (8-9): 913-924.

PAulus, H. F. 1979: Eye structure and the monophyly of the Arthropoda. - In: GuptA, A. P. 1979: Arthropod Phylogeny. - New York: Van Nostrand/Reinhold: pp. 299-383.

Paulus, H. F. 1986a: Comparative Morphology of the Larval Eyes of Neuropteroidea. - In: GEPP, J.; Aspöck, H. \& HöLzel, H. 1986 Recent Research in Neuropterology: - Proc. 2nd Symp Neuropterology Hamburg: pp. 157-164.

Paulus, H. F. 1986b: Evolutionswege zum Larvalauge der Insekten - ein Modell für die Entstehung und die Ableitung der ozellären Lateralaugen der Myriapoda von Fazettenaugen. - Zoologische Jahrbücher Systematik, Jena 113 (3): 353-371.

Paulus, H. F. 1989: Das Homologisieren in der Feinstrukturforschung: Das Bolwig-Organ der höheren Dipteren und seine Homologisierung mit Stemmata und Ommatidien eines ursprünglichen Fazettenauges der Mandibulata. - Zoologische Beiträge N.F., New York 32 (3): 437-478.

Plautz, J. D.; Day, R. N.; Dailey, G. M.; Welsh, S. B.; Hall, J. C.; Halpain, S. \& KaY, S. A. 1996: Green fluorescent protein and its derivatives as versatile markers for gene expression in living Drosophila melanogaster, plant and mammalian cells. - Gene, Amsterdam 173 (1): 83-87.

Quiring, R.; Walldorf, U.; Kloter, U.\&Gehring, W. J. 1994: Homology of the eyeless gene of Drosophila to the Small eye Gene in Mice and Aniridia Humans. Science, Washington, DC 265 (5173): 785-789.
READY, D. F. 1989: A multifaceted approach to neural development. - Trends in Neurosciences, Amsterdam 12 (3): 102-110.

Rottmar, B. 1966: Über Züchtung, Diapause und postembryonale Entwicklung von Panorpa communis L. - Zoologische Jahrbücher. Abteilung für Anatomie und Ontogenie der Tiere, Jena 83 (3): 497-570.

Salzer, C. L. \& Kumar, J. P. 2009: Position dependent responses to discontinuities in the retinal determinatrion network. - Developmental Biology, San Diego 326 (1): 121-130.

Schulz, W.-D.; Schlüter, U. \& SeIfert, G. 1984: Extraocular photoreceptors in the brain of Epilachna varivestis (Coleoptera, Coccinellidae). - Cell and Tissue Research, Heidelberg 236 (2): 317-320.

SEN, A. 2006: Optomotor-blind and the Horizontal and Vertical System cells of the Drosophila optic lobes: Molecular and laser ablation studies. - Mainz: Universität Mainz Fb. Biologie, Dissertation: pp. 122.

Serikaku, M. A. \& O'Tousa, J. E. 1994: Sine oculis Is a Homeobox Gene Required for Drosophila Visual System Development. - Genetics, Bethesda, MD 138 (4): 1137-1150.

SteinberG, A. G. 1941: A reconsideration of the mode of development of the bar eye of Drosophila melanogaster. - Genetics, Bethesda, MD 26 (3): 325-346.

SuZUKi, T. \& SAIGO, K. 2000: Transcriptional regulation of atonal required for Drosophila larval eye development by concerted action of Eyes absent, Sine oculis and Hedgehog signaling independent of Fused kinase and Cubitus interruptus. - Development, Cambridge 127 (7): 1531-1540.

Tomlinson, A. 1988: Cellular interactions in the developing Drosophila eye. - Development, Cambridge 104 (2): 183-193.

Truman, J. W. \& Riddiford, L. M. 1999: The origins of insect metamorphosis. - Nature, London 401 (6752): 447-452.

Truman, J. W. \& Riddiford, L. M. 2002: Endocrine insights into the evolution of metamorphosis in insects. - Annual Review of Entomology, Palo Alto 47 (1): 467-500.

WolfF, T. \& ReAdy, D. F. 1993: Pattern formation in the Drosophila retina. - In: BATE, M. and MARTINEZArias, A. 1993: The development of Drosophila melanogaster. - Woodbury, NY: Cold Spring Harbor Laboratory Press: pp. 1277-1325.

Wolpert, L. 1969: Positional Information and the Spatial Pattern of Cellular Differentiation. - Journal of Theoretical Biology, London 25 (1): 1-47.

Yasuyama, K. \& Meinertzhagen, I. A. 1999: Extraretinal Photoreceptors at the Compound Eye's Posterior Margin in Drosophila melanogaster. Journal of Comparative Neurology, Hoboken, NJ 412 (2): 193-202. 